\title{
Modelling and simulation of working processes in Wankel engine with direct hydrogen injection system
}

\begin{abstract}
Wankel engines were very attractive in automotive sector almost forty years ago because of small dimensions, compactness, simple design, smoothness of engine work and lack of vibration caused by inertia forces. The disadvantage of such engine was very high pollution, especially of hydrocarbons and carbon monoxide and high fuel consumption. These disadvantages can be eliminated by applying of direct injection of hydrogen and in the aviation sector by applying of fuel with high octane number also at a direct injection system. The main objective of the work is modelling of the thermodynamic process taking place during the scavenge process in such engine. At assumed geometry of the engine, initial and boundary conditions the change of engine parameters such as pressure, temperature, density, heat exchange and volume are calculated on the base of zero-dimensional model as a function of rotation angle of the piston. Forming of the mixture during fuel injection process in compression process gives information about the air excess ratio. The presented model is applicable for different sort of fuels. This work is introduction to a broader analysis of the processes in spatial system. Application of hydrogen reduces of toxic components emission from such engine, but decreases also engine power.
\end{abstract}

Key words: combustion engines, Wankel engine, scavenging process, hydrogen combustion

\section{Modelowanie i symulacja procesów roboczych w silniku Wankla z bezpośrednim wtryskiem wodoru}

Silnik Wankla byl bardzo interesujący dla przemystu samochodowego prawie czterdzieści lat temu ze względu na małe wymiary, kompaktowość, prosta konstrukcję, równomierność pracy silnika i brak drgań wywołanych siłami bezwładności. Wada tego silnika była duża toksyczność emitowanych spalin, szczególnie węglowodorów i tlenków azotu oraz duże zużycie paliwa. Te niedoskonałości silnika moga być wyeliminowane dzięki zastosowaniu bezpośredniego wtrysku paliwa o dużej liczbie oktanowej lub wodoru. Gtównym celem pracy jest modelowanie parametrów termodynamicznych procesów zachodzacych $w$ czasie przeptukania $w$ tym silniku. Przy założonych parametrach geometrycznych silnika, warunkach brzegowych i początkowych obliczono zmiany parametrów takich, jak: ciśnienie, temperatura, gęstość, prędkości wlotu i wylotu za pomoca własnego programu komputerowego opartego na modelu 0-D w funkcji kata obrotu wału korbowego. Tworzenie mieszanki podczas wtrysku paliwa daje informację o wspótczynniku nadmiaru powietrza. Zaprezentowany model obliczeniowy jest dostosowany do różnego rodzaju paliwa. Praca jest wstępem do szerszej analizy procesów przestrzennych $w$ komorze spalania. Zastosowanie wodoru zmniejsza emisję szkodliwych składników spalin, lecz zmniejsza również moc silnika.

Słowa kluczowe: silniki spalinowe, silnik Wankla, przeplukanie, spalanie wodoru

\section{Introduction}

History of rotary Wankel engine [2] is very long and expectations for it were very large. Working principles of that engine were described in many papers and elaborations $[1,7,8,15]$ concerning geometry, trajectory of the rotary piston and sealing. Features of this engine include: smoother rotational speed as a result of smaller inertia forces, higher rotational speed, smaller size in comparison to traditional valve engines, high specific power density, multifuel capability and compactness. The engine has also an advantage over four stroke engine that it can take several work cycles (usually three) during one piston rotation for one piston depending on engine design.

The disadvantage of such engine was very high exhaust gases pollution, especially of hydrocarbons and carbon monoxide and high fuel consumption. Wankel engine works as two-stroke engine with outflow (exhaust) and inflow ports located on the lateral side walls or on peripheral of epitrochoid. In addition the rotary engines have fewer parts than reciprocating engines. Their main problems are caused

\section{Wstęp}

Historia silnika Wankla [2] z obrotowym tłokiem jest bardzo długa, a oczekiwania względem niego były bardzo duże. Zasada działania tego silnika była przedstawiona w wielu artykułach naukowych i licznych opracowaniach $[1,7,8,15]$ dotyczących geometrii, trajektorii ruchu obrotowego tłoka oraz uszczelnienia. Zaletami tego silnika są: równomierność prędkości obrotowej jako wynik mniejszych sił bezwładności, osiąganie dużych prędkości obrotowych, mniejsze wymiary w porównaniu do tradycyjnego silnika zaworowego tej samej mocy, duża jednostkowa masowa moc, możliwość wielopaliwowości oraz duża zwartość budowy. Silnik jest lepszy od silnika czterosuwowego, ponieważ w czasie jednego obrotu tłoka wykonywanych jest kilka cykli roboczych (zazwyczaj trzy) dla jednego tłoka, zależnie od konstrukcji silnika.

Wadą tego silnika jest bardzo duża emisja szkodliwych składników spalin, szczególnie węglowodorów i tlenku węgla oraz duże zużycie paliwa. Silnik Wankla pracuje $\mathrm{w}$ trybie silnika dwusuwowego z oknami wylotowymi 
by leakage through the rotor apex seals and housing. It was considered by many researchers $[1,8,9]$. The direct injection stratified charge (DISC) are particularly advantageous in areas, where availability of aviation fuel is limited. The paper performs the scavenge process of Wankel engine with specified geometry and location of inlet and exhaust ports in order to explain the causes of air-fuel mixture formation in the combustion chamber with variable geometry. In order to decrease emission of exhaust gas pollutants the direct fuel injection of hydrogen was considered.

The work is done on the basis of results obtained from simulation program based on $0-\mathrm{D}$ model of combustion process with single zone and 1-D code of gas flow in inlet and outlet pipes. Heat transfer and mechanical losses were included in the model. Wankel engine can be considered as a power source in aviation due to compactness, smoothing work and high power density. In the world literature there is little positions concerning the scavenge process in Wankel engine. Recently many experimental works have been done in development of modern Wankel engines, for instance by Mazda researchers in 2004 [3].

\section{Geometry of Wankel engine}

The geometry of Wankel engine was presented in many papers, however, the given mathematical formulas sometimes differs with reality. A new approach of describing of Wankel engine was done by Warren [11] in his doctoral dissertation in 2012 and also by Zhao et al [15] for determination of trajectory of pump with Wankel geometry. The triangular shape of the piston causes that the internal shape of cylinder is described by close curve in a function of epitrochoide. The housing contour design with flow of compressed gas was given by Ma, Kuo and Chen [12] in 2010.

The overall geometry of the Wankel engine with outlet and inlet ports is shown in Fig. 1. Between outer housing shape and piston apex is the seal with length a. In order to decrease compression ratio the piston has small chamber, which increases combustion chamber volume. In Fig. 1 it is a bowl of small depth. Rotation of the piston relative to the central axis regarding to crank rotation is three times lower. Each point (point A) of epitrochoide is described by two equations:

$$
\begin{aligned}
& \mathrm{x}_{\mathrm{A}}=\mathrm{e} \cos \alpha+(\mathrm{R}+\mathrm{a}) \cos \beta \\
& \mathrm{y}_{\mathrm{A}}=\mathrm{e} \sin \alpha+(\mathrm{R}+\mathrm{a}) \sin \beta
\end{aligned}
$$

where: $\alpha=3 \beta-$ crank rotation angle, $\mathrm{e}-$ crank radius, $\mathrm{R}-$ length from apex to piston centre, $\mathrm{a}$ - seal length.

Chamber volume and surfaces of the chamber are a function of crank angle rotation $\alpha$ and geometry $(R, e, \rho)$. In order to perform the engine working process volume and surfaces were calculated for every crank rotation angle.

The areas of the surfaces were calculated by subtracting the areas contained within the lateral surfaces of the piston from the surface located between the straight lines connecting the axle of the crankshaft to the adjacent corners of the piston. The areas were determined from geometrical i dolotowymi umieszczonymi w płaszczyźnie bocznej lub na pobocznicy epitrochoidy. Silnik ma także mniej części niż tradycyjny silnik tłokowy. Głównym problemem w silniku jest uszczelnienie wierzchołków tłoka względem pobocznicy epitrochoidy i bocznych powierzchni. Było to tematem rozważań wielu badaczy $[1,8,9]$. Bezpośredni wtrysk paliwa tworzący ładunek uwarstwiony (DISC) ma szczególne znaczenie w tych obszarach lotnictwa, gdzie zużycie paliwa jest ograniczone. Praca przedstawia proces przepłukania w silniku Wankla o określonej geometrii i umieszczeniu okna wylotowego i dolotowego w celu wyjaśnienia przyczyn formowania mieszanki paliwowo-powietrznej w komorze spalania o zmiennej geometrii. W celu zmniejszenia emisji szkodliwych składników spalin rozważany jest bezpośredni wtrysk wodoru.

Pracę wykonano na podstawie wyników otrzymanych z symulacji numerycznej pracy silnika przeprowadzonej w programie komputerowym opracowanym przez autora i opartym na modelu 0 -D jednostrefowego procesu spalania oraz modelu 1-D nieustalonego przepływu gazu w przewodzie dolotowym i wylotowym. Wymianę ciepła oraz straty mechaniczne również uwzględniono w modelu. Silnik Wankla może być rozważany jako źródło napędu w lotnictwie z powodu zwartości konstrukcji, równomierności pracy oraz dużej gęstości mocy. W literaturze światowej jest bardzo mało pozycji dotyczących procesu przepłukania w silniku Wankla. W ostatnich latach wykonano natomiast dużo prac badawczych nad rozwojem silników Wankla, np. przez badaczy firmy Mazda w roku 2004 [3].

\section{Geometria silnika Wankla}

Zależności geometryczne w silniku Wankla były przedstawione w wielu pracach, jednakże podawane wzory matematyczne czasami różnią się od rzeczywistości. Nowego

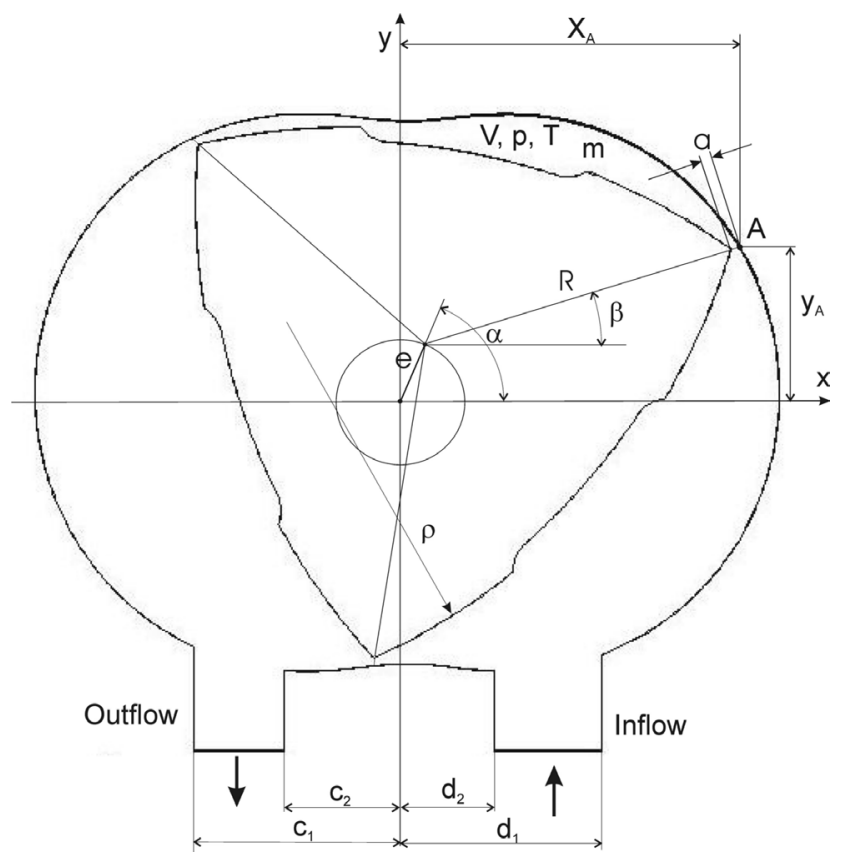

Fig. 1. Geometrical diagram of Wankel engine Rys. 1. Szkic geometrii silnika Wankla 
dependencies as a function of crank rotation in radians and are given below:

$$
\begin{gathered}
\mathrm{F}_{1}=\pi\left(\mathrm{e}^{2}+\frac{1}{3} \mathrm{R}^{2}\right)-\sqrt{3} \mathrm{e} \mathrm{R} \sin \left(\frac{2}{3}\left(\alpha+\frac{\pi}{6}\right)\right) \\
\mathrm{F}_{2}=0.5 \mathrm{e} \mathrm{R} \sin \frac{2}{3} \alpha \\
\mathrm{F}_{3}=0.5 \mathrm{e} \mathrm{R} \sin \left(\frac{2}{3}(\pi-\alpha)\right) \\
\mathrm{F}_{4}=\frac{\sqrt{3}}{4} \mathrm{R}^{2}+\rho^{2} \arcsin \left(\frac{\sqrt{3}}{2} \frac{\mathrm{R}}{\rho}\right) \\
-\frac{\sqrt{3}}{2} \mathrm{R} \rho \sqrt{1-\frac{3}{4}\left(\frac{\mathrm{R}}{\rho}\right)^{2}}
\end{gathered}
$$

The side area between piston and epitrochoide shapes amounts:

$$
\mathrm{F}_{\mathrm{c}}=\mathrm{F}_{1}-\mathrm{F}_{2}-\mathrm{F}_{3}-\mathrm{F}_{4}
$$

The changeable volume $\mathrm{V}$ of the combustion chamber is a function of side area and width $b$ of the piston:

$$
\mathrm{V}=\mathrm{F}_{\mathrm{c}} \mathrm{b}
$$

During one rotation of the rotary piston the crankshaft rotates three times (1080 deg CA). The equations (3)-(8) determine changing of the combustion chamber volume in a function of crankshaft angle rotation. The following main geometrical parameters are assumed: $\mathrm{R}=89 \mathrm{~mm}, \mathrm{e}=14$ $\mathrm{mm}, \rho=197 \mathrm{~mm}, \mathrm{~b}=70 \mathrm{~mm}, \mathrm{a}=2 \mathrm{~mm}$.

For such assumed geometrical parameters of Wankel engine it was possible to predict variation of volumes of one of three engine chambers in a function of crank angle rotation. Figure 2 presents a change of chamber volume for considered engine.

During three crankshaft rotations the chamber volume changes two times, because the ratio of tooth gears (internal in the rotors and the constant gear mounted in the housing) amounts $3 / 2$.

\section{Scavenge process in Wankel engine}

Amount of a delivered air and fuel influence on the work done by engine. Mixture formation and flow in Wankel engine were considered by Izweik [10] in his doctor thesis. Location of the outflow and inflow ports regarding to the centre of the housing decides on area-timing parameters of inflow and outflow processes. In the Fig. 1 values $c_{1}$ and $\mathrm{c}_{2}$ are distances between central axis $\mathrm{y}$ and beginning and closing edges of the exhaust port. On the other hand values $\mathrm{d}_{1}$ and $\mathrm{d}_{2}$ are distances between central axis $\mathrm{y}$ and closing and beginning edges of inlet port. podejścia do opisu silnika Wankla dokonał Warren [12] w roku 2012, a także Zhao i inni [15] w celu określenia trajektorii ruchu tłoka pompy opartej na geometrii silnika Wankla. Trójkątny kształt tłoka powoduje, że wewnętrzny kształt cylindra jest opisany przez krzywą zbliżoną do epitrochoidy. Wewnętrzny zarys obudowy, a także przepływ gazu był podany przez Ma, Kuo i Chen [12] w roku 2010.

Ogólny zarys geometrii silnika Wankla z oknem wylotowym i dolotowym pokazano na rys. 1. Między wewnętrznym kształtem obudowy i wierzchołkami tłoka jest uszczelnienie o długości a. W celu zmniejszenia stopnia sprężania tłok posiada małe wgłębienia, które zwiększają objętość komory spalania - na rys. 1 jest to czasza o małej głębokości. Obrót tłoka określony w centralnych osiach układu odniesienia w stosunku do obrotu wykorbienia jest trzykrotnie mniejszy. Każdy punkt (punkt A) epitrochoidy jest opisany dwoma równaniami (1) i (2),

gdzie: $\alpha=3 \beta$ - kąt obrotu wykorbienia, e - promień wykorbienia, R - odległość od wierzchołka do środka tłoka, a-długość uszczelnienia.

Objętość komory oraz pola powierzchni komory są funkcją kata obrotu wykorbienia $\alpha$ (oraz parametrami geometrycznymi $(\mathrm{R}, \mathrm{e}, \rho))$. W celu określenia procesu roboczego silnika objętość komory i pola powierzchni obliczano dla każdego kąta obrotu wykorbienia.

Pola powierzchni obliczano przez odejmowanie powierzchni zawartych wewnątrz powierzchni bocznych tłoka od powierzchni znajdującej się między prostymi odcinkami łączącymi oś obrotu wykorbienia i sąsiednie wierzchołki tłoka. Pola powierzchni są określone z geometrycznych zależności jako funkcje kąta obrotu wykorbienia $\mathrm{w}$ radianach: $(3)-(6)$.

Pole powierzchni bocznej między tłokiem i zarysem epitrochoidy wynosi (7).

Zmienna objętość V komory spalania jest funkcją powierzchni bocznej i szerokości b tłoka - wzór (8).

Podczas jednego obrotu tłoka wykorbienie obraca się trzy razy $\left(1080^{\circ} \mathrm{OWK}\right)$. Równania (3)-(8) wyznaczają zmianę objętości komory spalania w funkcji kąta obrotu wału kor-

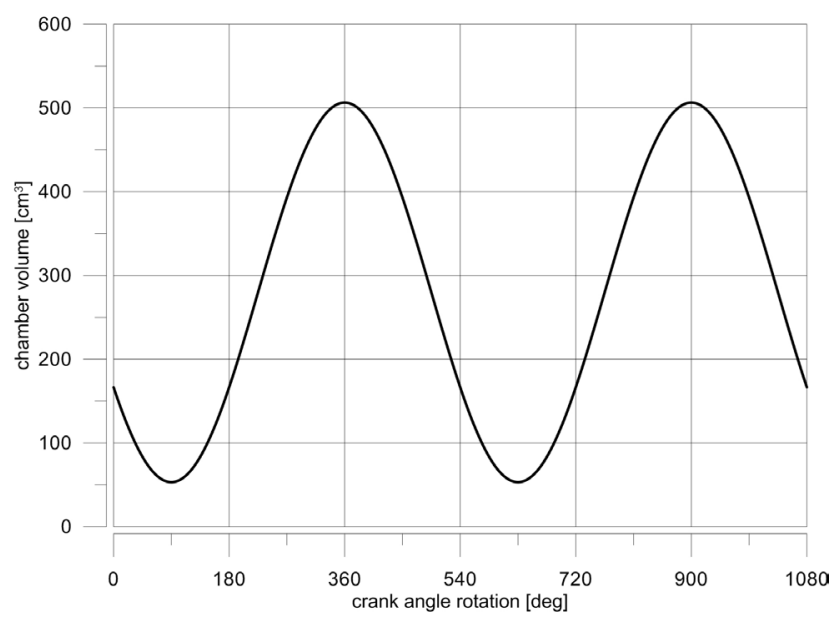

Fig. 2. Change of volume in function of crank rotation angle Rys. 2. Zmiana objętości komory w funkcji kąta obrotu wykorbienia 
The area of every port decides about mass flow rate from the combustion chamber to the exhaust pipe or from the inlet pipe to the combustion chamber.

Mixture inflow to the work chamber takes place as a result of pressure difference between the inlet port $p_{\text {in }}$ and the work chamber $\mathrm{p}_{1}$ :

- for critical inflow when $\mathrm{p}_{1} / \mathrm{p}_{\text {in }}<0.528$ :

$$
\dot{\mathrm{m}}_{\text {in }}=\varphi_{\text {in }} \mathrm{F}_{\text {in }} \mathrm{p}_{\text {in }} \sqrt{\frac{\mathrm{k}}{\mathrm{RT}_{\text {in }}}\left(\frac{2}{\mathrm{k}+1}\right)^{\frac{\mathrm{k}+1}{\mathrm{k}-1}}}
$$

- for subcritical flow when $\mathrm{p}_{1} / \mathrm{p}_{\text {in }}>0.528$ :

$$
\dot{\mathrm{m}}_{\text {in }}=\varphi_{\text {in }} \mathrm{F}_{\text {in }} \mathrm{p}_{\text {in }} \sqrt{\frac{2}{\mathrm{RT}_{\text {in }}} \frac{\mathrm{k}}{\mathrm{k}-1}\left(\frac{\mathrm{p}_{1}}{\mathrm{p}_{\text {in }}}\right)^{\frac{2}{\mathrm{k}}}\left[1-\left(\frac{\mathrm{p}_{1}}{\mathrm{p}_{\text {in }}}\right)^{\frac{\mathrm{k}-1}{\mathrm{k}}}\right]}
$$

where $\varphi_{\text {in }}$ is flow coefficient taking into account flow losses (normally $\varphi_{\text {in }} \approx 0.8$ ), $\mathrm{k}$ is specific heats ratio $\mathrm{k}=\mathrm{c}_{\mathrm{p}} / \mathrm{c}_{\mathrm{v}}$ and $\mathrm{R}$ is an individual gas constant.

The inlet port area $\mathrm{F}_{\text {in }}$ is calculated on an ongoing basis using eq. (1) and defined geometrical parameters $d_{1}$ and $d_{2}$ where $\mathrm{x}=\mathrm{d}_{1}$ or $\mathrm{x}=\mathrm{d}_{2}$. For such values we can find the opening and closing angles of the crankshaft concerning the inlet port. The same procedure is done for determination of opening and closing angles for the exhaust port. The opening area is a function of opening length of the port and its width.

Outflow of gases from work chamber to the exhaust pipe occurs when pressure $p_{1}$ is bigger than pressure $p_{\text {exh }}$ in the exhaust port with. For that case the similar dependencies can be written:

- for critical flow $\left(\mathrm{p}_{\mathrm{exh}} / \mathrm{p}_{1}<0.528\right)$ :

$$
\dot{\mathrm{m}}_{\text {out }}=\varphi_{\text {exh }} \mathrm{F}_{\text {exh }} \mathrm{p}_{1} \sqrt{\frac{\mathrm{k}}{\mathrm{RT}_{1}}\left(\frac{2}{\mathrm{k}+1}\right)^{\frac{\mathrm{k}+1}{\mathrm{k}-1}}}
$$

- for subcritical outflow when $\mathrm{p}_{2} / \mathrm{p}_{1}>0.528$ the mass flow rate is obtained from the following formula:

$\dot{\mathrm{m}}_{\text {out }}=\varphi_{\text {exh }} \mathrm{F}_{\text {exh }} \mathrm{p}_{1} \sqrt{\frac{2}{\mathrm{RT}_{1}} \frac{\mathrm{k}}{\mathrm{k}-1}\left(\frac{\mathrm{p}_{\text {exh }}}{\mathrm{p}_{1}}\right)^{\frac{2}{\mathrm{k}}}\left[1-\left(\frac{\mathrm{p}_{\text {exh }}}{\mathrm{p}_{1}}\right)^{\frac{\mathrm{k}-1}{\mathrm{k}}}\right]}$

Flow coefficient $\varphi_{\text {exh }}$ has changeable value during opening the exhaust port and that parameter is lower than 1.0.

Pressure $p_{\text {in }}$ and $p_{\text {exh }}$ in the ports are superposition pressure of reflective and positive pressure waves when nonlinear gas motion in the pipes are considered.

Theoretical timing of opening the ports is shown in Fig. 3 for one working chamber. When one of the apexes is closing the port for one chamber the next chamber is connected with the same port. This phenomenon influences on gas flow in the port. The gas can flow from the working chamber to the next chamber or in reverse direction. bowego. Przyjęto następujące parametry geometryczne: $\mathrm{R}=$ $89 \mathrm{~mm}, \mathrm{e}=14 \mathrm{~mm}, \rho=197 \mathrm{~mm}, \mathrm{~b}=70 \mathrm{~mm}, \mathrm{a}=2 \mathrm{~mm}$.

Dla tak przyjętych parametrów geometrycznych silnika Wankla było możliwe wyznaczenie zmiany objętości jednej z trzech komór w funkcji kąta obrotu wału korbowego. Rysunek 2 przedstawia zmianę objętości komory dla rozważanego silnika. Podczas trzech obrotów wału korbowego objętość komory zmienia się 2 razy, ponieważ stosunek zazębienia kół zębatych (wewnętrznego w wirniku i stałego zazębienia w obudowie) wynosi $3 / 2$.

\section{Proces przepłukania w silniku Wankla}

Ilość dostarczonego powietrza i paliwa wpływa na wielkość pracy wykonanej przez silnik. Tworzenie mieszanki i przepływ gazu w silniku Wankla były rozważane przez Izweika [10]. Usytuowanie okna wylotowego oraz dolotowego w odniesieniu do osi centralnych obudowy decyduje o parametrach rozrządu (czasoprzekrojach) wylotu i dolotu. $\mathrm{Na}$ rysunku 1 wielkości $\mathrm{c}_{1}$ i c $\mathrm{c}_{2}$ są odległościami między centralną osią y i początkową oraz końcową krawędzią okna wylotowego. Wielkości $\mathrm{d}_{1} \mathrm{i} \mathrm{d}_{2}$ są natomiast odległościami między centralną osią y a zamykającą oraz początkową krawędzią okna dolotowego.

Pole powierzchni każdej szczeliny wpływa na masowe natężenie przepływu ładunku z komory spalania do kanału wylotowego, albo z przewodu dolotowego do komory spalania. Wlot ładunku do komory spalania występuje $\mathrm{w}$ wyniku różnicy ciśnień między szczeliną dolotową $\mathrm{p}_{\text {in }}$ i komorą roboczą $\mathrm{p}_{1}$ :

- dla przepływu krytycznego $\left(\mathrm{p}_{1} / \mathrm{p}_{\mathrm{in}}<0.528\right)$ - wzór (9),

- dla przepływu podkrytycznego, kiedy $\mathrm{p}_{1} / \mathrm{p}_{\text {in }}>0.528-$ wzór (10), gdzie $\varphi_{\text {in }}$ jest współczynnikiem przepływu uwzględniającym straty przepływu gazu (zazwyczaj $\left.\varphi_{\text {in }} \approx 0.8\right), \mathrm{k}-$ stosunkiem ciepeł właściwych $\mathrm{k}=\mathrm{c}_{\mathrm{p}} / \mathrm{c}_{\mathrm{v}}$, a R - indywidualną stałą gazową ładunku.

Pole powierzchni szczeliny wlotowej $F_{\text {in }}$ jest obliczane na bieżąco przy wykorzystaniu równania (1) oraz założonych wielkości geometrycznych $\mathrm{d}_{1} \mathrm{i} \mathrm{d}_{2}$, gdzie $\mathrm{x}=\mathrm{d}_{1}$ albo $\mathrm{x}=\mathrm{d}_{2}$. Dla takich wartości można znaleźć kąty otwarcia i zamknięcia szczeliny dolotowej w funkcji kąta obrotu wykorbienia. Taka sama procedura jest wykonywana do określenia kątów otwarcia i zamknięcia szczeliny wylotowej. Pole otwarcia każdej ze szczelin jest funkcją długości otwarcia okna i jego szerokości.

Wylot gazów z komory roboczej do układu wylotowego występuje wtedy, gdy ciśnienie $\mathrm{p}_{1}$ jest większe niż ciśnienie $\mathrm{p}_{\text {exh }}$ w szczelinie wylotowej. Dla tego przypadku mogą być napisane podobne zależności:

- dla przepływu krytycznego $\left(\mathrm{p}_{\text {exh }} / \mathrm{p}_{1}<0.528\right)$ - wzór (11),

- dla przepływu podkrytycznego, kiedy $\mathrm{p}_{2} / \mathrm{p}_{1}>0.528$ masowe natężenie przepływu gazu jest otrzymywane z zależności (12).

Współczynnik przepływu $\varphi_{\text {exh }}$ ma zmienną wartość podczas otwarcia szczeliny wylotowej i jest mniejszy niż 1,0. Ciśnienia $\mathrm{p}_{\text {in }}$ i $\mathrm{p}_{\text {exh }}$ w szczelinach są superpozycją fali ciśnienia dodatniego i odbitego wtedy, gdy rozważany jest nieustalony przepływ gazu w przewodach. 
This figure shows opening port ratio as follows:

$$
\psi=\frac{\mathrm{F}_{\text {port }}}{\mathrm{F}_{\text {max }}}
$$

where $\mathrm{F}_{\text {port }}$ - current area of the port, $\mathrm{F}_{\text {max }}$ - maximum of the port area.

\section{Energy balance}

An increase of mass in the chamber $\dot{\mathrm{m}}_{\mathrm{ch}}$ occurs during scavenge process (exhaust mass flow rate $\dot{\mathrm{m}}_{\mathrm{exh}}$ and inlet mass flow rate $\dot{m}_{\text {in }}$ ) and fuel injection $\dot{m}_{\text {inj }}$. Then in Wankel engine the mass balance can be presented in the following form:

$$
\dot{\mathrm{m}}_{\mathrm{in}}+\dot{\mathrm{m}}_{\mathrm{inj}}-\dot{\mathrm{m}}_{\mathrm{exh}}+\dot{\mathrm{m}}_{\mathrm{ch}}=0
$$

For single zone model of spark ignition engine rotary engine the first law of thermodynamics can be applied:

$$
\begin{aligned}
& \frac{d E}{d \theta}=\frac{d Q_{s}}{d \theta}-p \frac{d V}{d \theta}-\frac{d Q_{c}}{d \theta}-h_{C R} \frac{d m_{C R}}{d \theta}+h_{\text {in }} \frac{d m_{\text {in }}}{d \theta} \\
& -h_{\text {exh }} \frac{d m_{\text {exh }}}{d \theta}+h_{\text {inj }} \frac{d m_{\text {inj }}}{d \theta}
\end{aligned}
$$

where: $\mathrm{p}$ - pressure, $\mathrm{V}$ - volume, $\mathrm{E}$ - internal energy, $\theta$ crankshaft angle $(\theta=\omega \mathrm{t}), \mathrm{Q}_{\mathrm{s}}-$ combustion heat release, $\mathrm{Q}_{\mathrm{c}}$ - heat transfer losses, $\mathrm{h}_{\mathrm{CR}}$ - enthalpy of crevices losses, $h_{\text {in }}$ - enthalpy of inlet gases, $h_{\text {exh }}$ - enthalpy of exhaust gases, $\mathrm{h}_{\mathrm{inj}}$ - enthalpy of liquid fuel, $\mathrm{m}_{\mathrm{CR}}$ - crevice mass losses, $\mathrm{m}_{\mathrm{in}}$ - mass of gas flown trough the inlet port, $\mathrm{m}_{\mathrm{exh}}$ - mass of gas flown trough the exhaust port, $\mathrm{m}_{\mathrm{inj}}$ - injected mass of fuel.

On the basis of gas state equation from the eq. (15) we can determine pressure at every value of crank angle and next temperature in the working chamber.

\section{Fuel injection}

Mass flow rate of injected fuel depends on type of injector, pressure difference between two medium and fuel density. Mass flow rate is determined from Bernoulli equation concerning balance of pressure at point 1 and 2 [14]:

$$
\dot{\mathrm{m}}_{\text {inj }}=\mathrm{C}_{\mathrm{D}} \mathrm{F}_{\text {inj }} \sqrt{2 \rho_{\mathrm{f}} \Delta \mathrm{p}}
$$

where: $C_{D}-$ coefficient of flow losses in injector, $F_{\text {inj }}-$ fuel flow area in injector, $\rho_{\mathrm{f}}$ - fuel density, $\Delta \mathrm{p}$ - pressure difference between injector rail and gas in the working chamber.

Total mass of injected fuel during time $\Delta \mathrm{t}=\mathrm{t}_{2}-\mathrm{t}_{1}$ is calculated as follows:

$$
\mathrm{m}_{\mathrm{inj}}=\int_{\mathrm{t}_{1}}^{\mathrm{t}_{2}} \dot{\mathrm{m}}_{\mathrm{inj}} \mathrm{dt}
$$

Control system of direct hydrogen injection in Wankel engine was considered by Szlachetka et al [6] with CFD simulation of fuel propagation in the working chamber. Performance of a supercharged Wankel engine with fuel
Teoretyczny względny czasoprzekrój okna wylotowego i dolotowego jest przedstawiony na rys. 3 dla jednej komory roboczej. Kiedy jeden z wierzchołków tłoka przymyka okno dla jednej z komór, następna komora jest połączona z tym samym oknem. To zjawisko wpływa na przepływ gazu

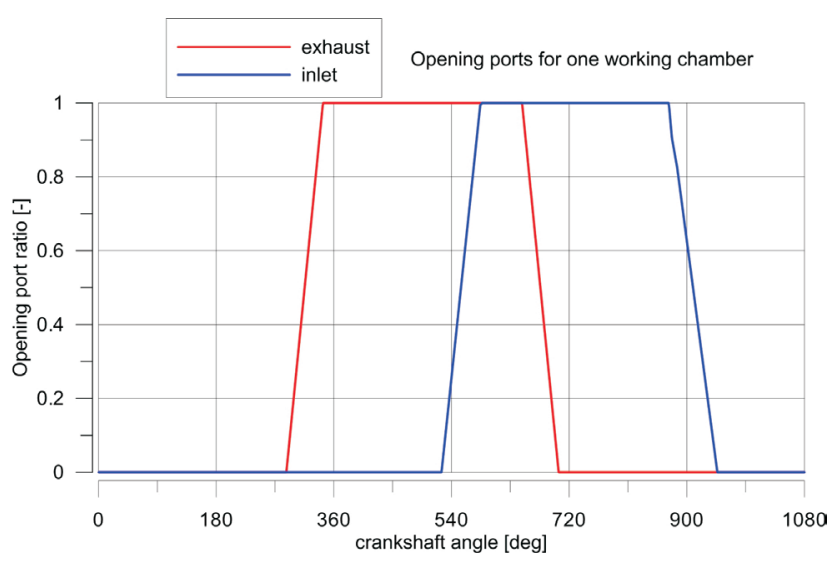

Fig. 3. Port timing in Wankel engine

Rys. 3. Rozrząd szczelinowy w silniku Wankla

w szczelinie. Gaz może przepływać z jednej komory roboczej do drugiej lub w odwrotnym kierunku.

Rysunek 3 przedstawia stopień otwarcia szczelin, jako wyrażenie (13),

gdzie: - bieżące pole otwarcia okna, - maksymalne pole otwarcia okna.

\section{Bilans energii}

Przyrost masy gazu w komorze $\dot{m}_{\text {ch }}$ następuje podczas procesu przepłukania (masowe natężenie przepływu spalin $\dot{\mathrm{m}}_{\text {exh }}$ oraz masowe natężenie przepływu ładunku na dolocie $\dot{\mathrm{m}}_{\mathrm{in}}$ ) oraz podczas wtrysku paliwa $\dot{\mathrm{m}}_{\text {inj }}$. W związku z tym równanie bilansu masy gazu w silniku Wankla może być przedstawione w postaci (14).

Dla jednostrefowego modelu fizycznego silnika z tłokiem obrotowym o zapłonie iskrowym może być zastosowana I zasada termodynamiki - równanie (15),

gdzie: p - ciśnienie, V - objętość komory roboczej, E energia wewnętrzna, $\theta$ - kąt obrotu wykorbienia $(\theta=\omega t)$, $\mathrm{Q}_{\mathrm{s}}$ - wydzielone ciepło spalania paliwa, $\mathrm{Q}_{\mathrm{c}}$ - straty wymiany ciepła, $h_{C R}-$ entalpia strat szczelinowych, $h_{i n}$ - entalpia gazów dolotowych, $\mathrm{h}_{\text {exh }}$ - entalpia gazów wylotowych, $\mathrm{h}_{\mathrm{inj}}$ - entalpia ciekłego paliwa, $\mathrm{m}_{\mathrm{CR}}$ - masowe straty szczelinowe, $\mathrm{m}_{\text {in }}$ - masa gazów wpływająca przez okno dolotowe, $\mathrm{m}_{\text {exh }}$ - masa gazów przepływająca przez okno wylotowe, $\mathrm{m}_{\mathrm{inj}}$ - wtryśnięta masa paliwa.

Na podstawie prawa stanu gazu z równania (15) można określić ciśnienie dla każdej wartości kąta obrotu wykorbienia, a następnie temperaturę ładunku w przestrzeni roboczej.

\section{Wtrysk paliwa}

Masowe natężenie przepływu paliwa zależy od typu wtryskiwacza, różnicy ciśnień między dwoma ośrodkami oraz gęstości paliwa; jest ono wyznaczane $\mathrm{z}$ równania 
direct injection forming a stratified charge was presented by Bartrand and Willis [5]. Fuel injection follows after closing the inlet port or shortly before that occurrence when injection pressure difference is high. Amount of injected fuel should confirm an assumed air-fuel ratio $\mathrm{A} / \mathrm{F}$ for different sort of fuel.

Therefore we have to know amount of air $\mathrm{m}_{\text {in }}$ delivered air to the working chamber. If the engine is fuelled by liquid fuel then evaporation process should be considered. For hydrogen-air mixture only the mixing and diffusion processes are considered.

Combustion process in Wankel engine like in a spark ignition engine can be treated in single zone model by application of Viebe function with assumption of combustion period $\Delta \theta_{\mathrm{s}}$. Another conception of ignition of engine was given by Votav [13], who presents a micropilot flame ignition strategy in engine with direct fuel injection in order to obtain a stratified charge.

\section{Numerical calculation of thermodynamic processes in Wankel engine}

The given above mathematical models of processes taking place in Wankel engine were the source of computer program worked by the author. The calculation program enables simulation of physical processes and determination of different thermodynamic parameters for assumed geometrical engine parameters. One of the first experimental and theoretical analyses was depicted by Keck and Heywood [4].

The program has simple graphical interface enabling observation of main parameters such as; pressure and temperature both in the chamber and connected pipes, gas velocity, pressure waves both in the pipes. The program takes into account non-steady gas flow in the pipe which enables determination of changeable pressure in the exhaust and inlet ports.

The program has sent the data to different text files, which are next used in graphical programs such as Excel or Grapher for preparation of graphical representation of obtained results.

All graphs presented in the paper were elaborated on the basis of results obtained from the simulation program. The program automatically calculates the timing areas of the ports for every step of calculation time or crank angle. The simulation has given initial values of thermodynamic parameters for CFD simulation particularly for analysis of scavenge, fuel injection and combustion processes.

\section{Results of calculation}

The analyzed rotary Wankel engine has full inlet and exhaust system. The results shown in the paper were obtained for constant geometrical parameters of engine and gas flow systems. One of the main task of the engine is obtaining high volumetric efficiency, which is a result of well scavenge process.

The air flow rate through the inlet port is presented in Fig. 4 for crankshaft rotation speeds: 4000 and $8000 \mathrm{rpm}$. At the first stage of opening of the inlet port the exhaust
Bernoulliego dotyczącego bilansu energii w punkcie 1 i 2 [14] - wzór (16),

gdzie: $\mathrm{C}_{\mathrm{D}}$ - współczynnik strat przepływu we wtryskiwaczu, $\mathrm{F}_{\text {inj }}$ - przekrój przepływowy paliwa wtryskiwacza, $\rho_{\mathrm{f}}-$ gęstość paliwa, $\Delta \mathrm{p}$ - różnica ciśnień między szyną paliwową i gazem w przestrzeni roboczej.

Całkowita masa wtryśniętego paliwa w czasie $\Delta \mathrm{t}=\mathrm{t}_{2}-\mathrm{t}_{1}$ jest obliczana według równania (17).

System sterowania bezpośrednim wtryskiem wodoru w silniku Wankla był rozważany przez Szlachetkę i in. [6] za pomocą symulacji CFD propagacji w komorze roboczej. Charakterystyki doładowanego mechanicznie silnika Wankla z bezpośrednim wtryskiem paliwa były przedstawione przez Bertranda i Willysa [5]. Wtrysk paliwa następuje po zamknięciu okna dolotowego albo krótko przed jego zamknięciem, co powoduje, że różnica ciśnień dwóch ośrodków jest duża. Ilość wtryśniętego paliwa powinna zapewniać założony stosunek A/F dla różnych rodzajów paliw.

Z tego powodu należy znać ilość doprowadzonego powietrza $\mathrm{m}_{\text {in }}$ do przestrzeni roboczej silnika. Jeżeli silnik jest zasilany ciekłym paliwem, wówczas należy rozważać proces odparowania. Dla gazowej mieszanki wodorowo-powietrznej rozpatrywany jest tylko proces mieszania i dyfuzji.

Proces spalania w silniku Wankla podobnie jak w innych silnikach o zapłonie iskrowym może być przedstawiony za pomocą modelu jednostrefowego przy zastosowaniu funkcji

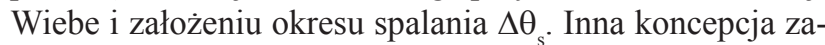
płonu w silniku została zaproponowana przez Votava [14], który przedstawił mikropilotową strategię zapłonu w silniku $\mathrm{z}$ bezpośrednim wtryskiem paliwa w celu uzyskania uwarstwionego ładunku.

\section{Obliczenia numeryczne procesu termodynamicznego w silniku Wankla}

Podany wyżej model matematyczny procesów zachodzących w silniku Wankla był źródłem powstałego programu komputerowego opracowanego przez autora tej pracy. Program obliczeniowy umożliwia symulację procesów fizycznych oraz określenie parametrów termodynamicznych przy założonych parametrach geometrycznych silnika. Jedna z pierwszych doświadczalnych i teoretycznych analiz została dokonana przez Kecka i Heywooda [4].

Program komputerowy ma prosty graficzny interface umożliwiający obserwację zmian głównych parametrów, takich jak: ciśnienie i temperatura zarówno w komorze, jak i przewodach, prędkość gazu, ciśnienie fal gazu w obydwu przewodach. Program komputerowy uwzględnia niestacjonarny przepływ gazu w przewodach, co umożliwia określenie zmienności ciśnienia w oknie dolotowym i wylotowym. Program przesyła dane do różnych plików tekstowych, które następnie są wykorzystane w graficznych programach, takich jak Excel czy Grapher, do przygotowania graficznej reprezentacji otrzymanych wyników obliczeń.

Wszystkie rysunki przedstawione w artykule opracowano na podstawie wyników otrzymanych z programu symulacyjnego. Program automatycznie oblicza czasoprzekroje okien dla każdego kroku obliczeń albo kąta obrotu wykorbienia. 


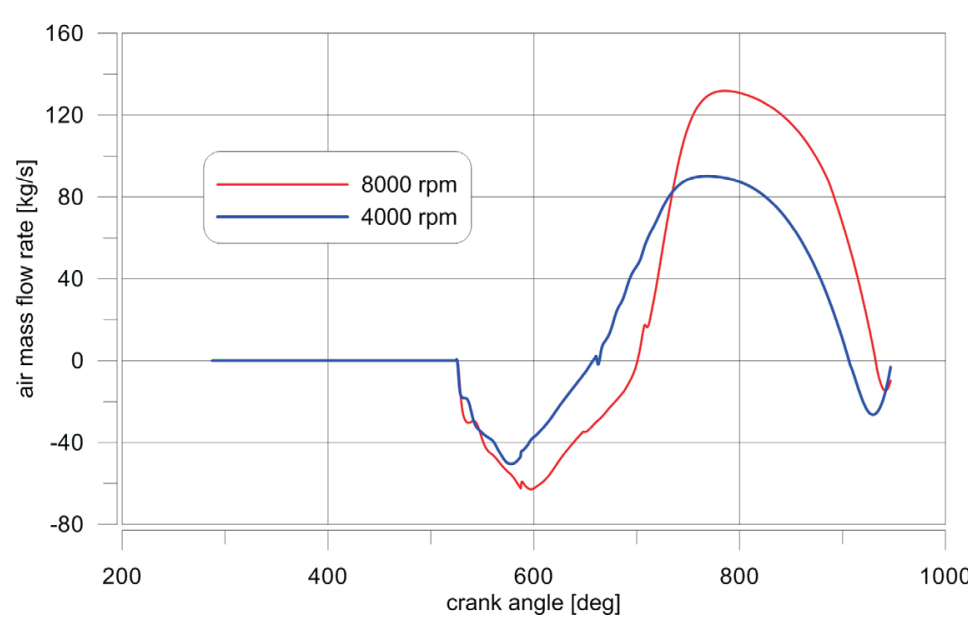

Fig. 4. Air mass flow rate through inlet port at 4000 and $8000 \mathrm{rpm}$ Rys. 4. Masowe natężenie przeptywu powietrza przez okno dolotowe przy prędkości obrotowej 4000 i $8000 \mathrm{obr} / \mathrm{min}$

gases at higher pressure causes an outflow of the air from the port and exhaust gases flow into the inlet duct. Next the compressed charge in the inlet pipe flows into the cylinder with high mass rate. At higher crankshaft rotational speed the higher air mass flow rate occurs. This phenomenon is caused by non-steady gas flow in the pipes. Despite the inlet port is open for a long period the real inflow of air takes place only during a half of this period.

Courses of pressure and gas velocity in the inlet port explain the scavenge process in the rotary Wankel engine. Figure 5 shows variations of pressure and gas velocity in the pipe before the inlet port at crankshaft rotational speed $6000 \mathrm{rpm}$. In the moment of opening of the port the exhaust gases in the working chamber have higher pressure than in the inlet pipe, which causes also higher pressure in the port. Lowest pressure amounts 0.92 bar at $720 \mathrm{deg}$ CA and for that work point highest gas velocity in the inlet port amounts $60 \mathrm{~m} / \mathrm{s}$. During closing of the inlet port by the rotor a strong oscillation of pressure occurs.

Non-steady gas flow in the exhaust port also causes a change of mass of exhaust gases leaving the working chamber. Course of total mass of exhaust gases is shown in Fig. 6 at rotational speeds 4000 and $8000 \mathrm{rpm}$. A return flow of gases in the exhaust pipe influences on decreasing of total mass of these gases as a result of reflection of pressure waves. Opening of the exhaust port lasts $400 \mathrm{deg}$ CA and total mass of gas leaving the chamber amount $0.3 \mathrm{~g}$ and is a little bit less for engine working at higher speed $8000 \mathrm{rpm}$. Variation of total mass of exhaust gases is almost the same for different rotational speeds for full opening of the air throttle.

Fluctuation of pressure in the exhaust pipe effects on a change of exhaust gas velocity, where the pipe had a short length $0.37 \mathrm{~m}$. Variation of exhaust gas for engine fuelled by gasoline and hydrogen is shown in Fig. 7 at rotational speed $6000 \mathrm{rpm}$ and air excess ratio $\lambda=1.05$. It can be
Symulacja daje wartości początkowe parametrów termodynamicznych dla symulacji procesów roboczych za pomocą programów CFD, szczególnie do analizy procesów przepłukania, wtrysku paliwa i spalania.

\section{Wyniki obliczeń}

Analizowany obrotowy silnik Wankla uwzgledniał pełny układ dolotowy i wylotowy. Wyniki obliczeń przedstawione w artykule otrzymano dla stałych parametrów geometrycznych silnika i układu przepływowego gazu. Jednym z głównych zadań silnika jest uzyskanie dużego stopnia napełnienia, który jest wynikiem dobrego procesu przepłukania.

Masowe natężenie przepływu powietrza przez okno dolotowe przedstawiono na rys. 4 dla prędkości obrotowej wykorbienia 4000 i $8000 \mathrm{obr} / \mathrm{min}$. W pierwszym etapie otwarcia okna dolotowego gazy wylotowe w komorze o dużym ciśnieniu powodują wypływ powietrza z okna dolotowego, a gazy spalinowe wlatują do kanału dolotowego. Następnie sprężone powietrze w przewodzie dolotowym wpływa do komory z dużym masowym natężeniem przepływu. Przy większej prędkości obrotowej występuje również większe masowe natężenie przepływu powietrza. To zjawisko jest spowodowane nieustalonym przepływem gazu w przewodach. Pomimo że okno dolotowe jest otwarte przez długi okres, rzeczywisty wlot powietrza występuje tylko w ciągu połowy tego okresu.

Przebieg ciśnienia i prędkości powietrza w oknie wlotowym wyjaśniają proces przepłukania w obrotowym silniku Wankla. Rysunek 5 przedstawia zmiany ciśnienia i prędkości gazu w przewodzie dolotowym bezpośrednio przed oknem dolotowym przy prędkości obrotowej wykorbienia 6000 $\mathrm{obr} / \mathrm{min}$. W chwili otwarcia okna dolotowego gazy spalinowe w komorze roboczej mają większe ciśnienie niż jest w ukła-

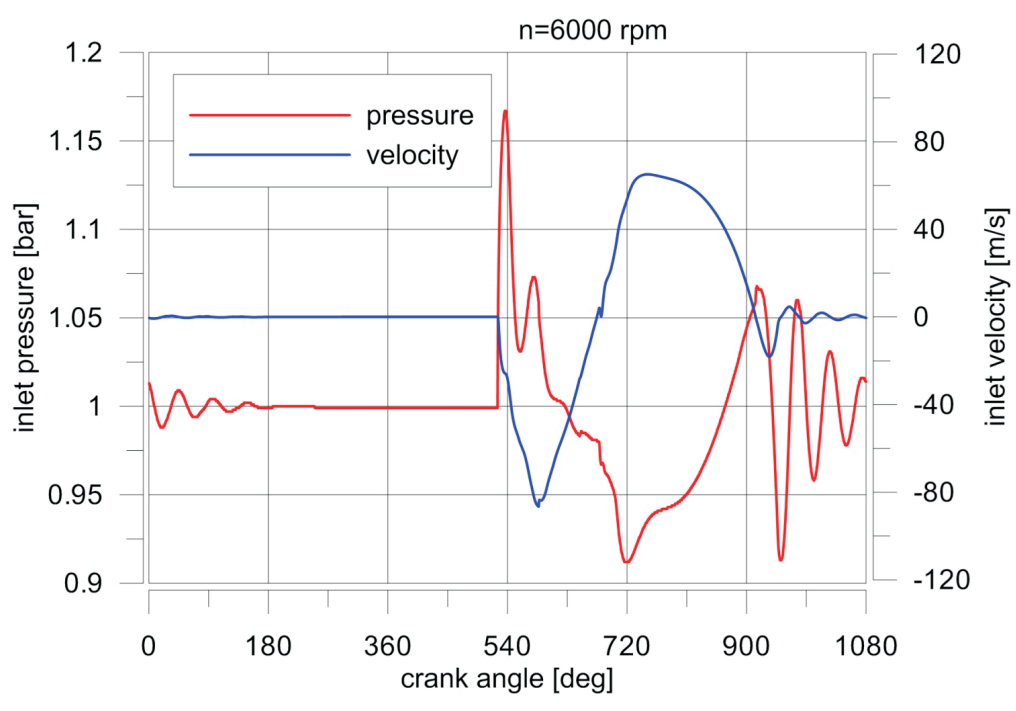

Fig. 5. Variation of pressure and air velocity before inlet port at $6000 \mathrm{rpm}$

Rys. 5. Zmiana ciśnienia i prędkości gazu przed oknem wlotowym przy prędkości obrotowej $6000 \mathrm{obr} / \mathrm{min}$ 


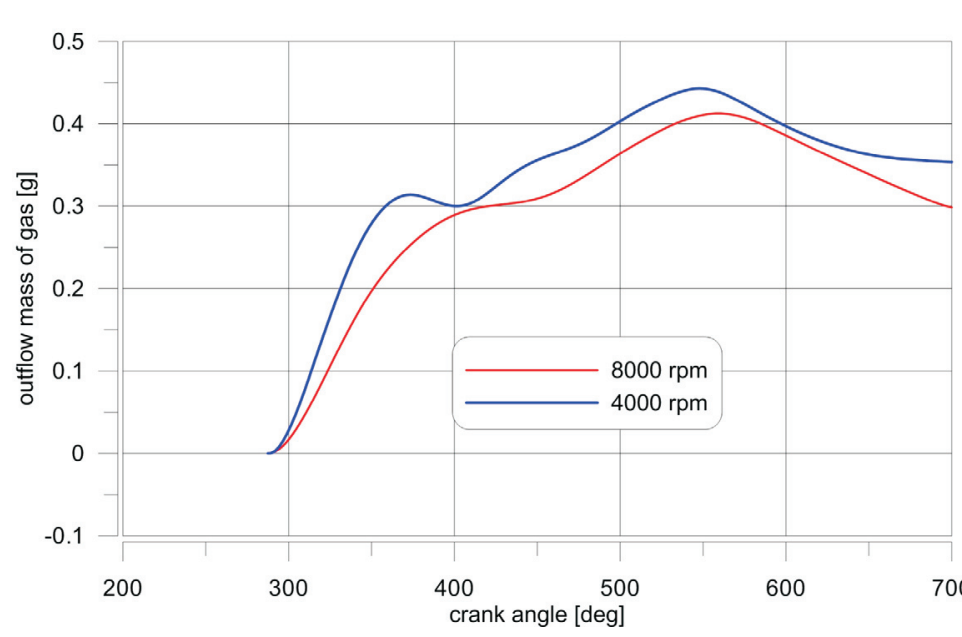

Fig. 6. Mass flow rate of exhaust gases at 4000 and $8000 \mathrm{rpm}$

Rys. 6. Masowe natężenie przepływu gazów spalinowych przy prędkości obrotowej 4000 i $8000 \mathrm{obr} / \mathrm{min}$

seen that any sort of fuel has no big influence on exhaust gases velocity. At the first period of opening of the exhaust port a big value of velocity about $360 \mathrm{~m} / \mathrm{s}$ is attained. At the end of opening of the exhaust port there is an inflow of the exhaust gases to the chamber (compare with Fig. 6).

Scavenge process decides about total mass of the charge in the chamber. Quantity of leaving gas to the exhaust port should be the same as quantity of the inflowing air. Variation of charge mass in the working chamber is presented in Fig. 8 for two rotational speed 4000 and $6000 \mathrm{rpm}$. Minimum of mass takes place at crankshaft location $630 \mathrm{deg}$ CA and amounts $0.019 \mathrm{~g}$. After closing of the inlet port mass of the charge amounts $0.458 \mathrm{~g}$. Variation of the mass in the chamber only slightly changes with crankshaft rotational speed.

During scavenge and combustion processes the quantity of exhaust gases and air changes. At air excess ratio $\lambda>1$ the exhaust gases contain some air. Mass ratio of air and fuel to total mass of charge is increasing during induction process,

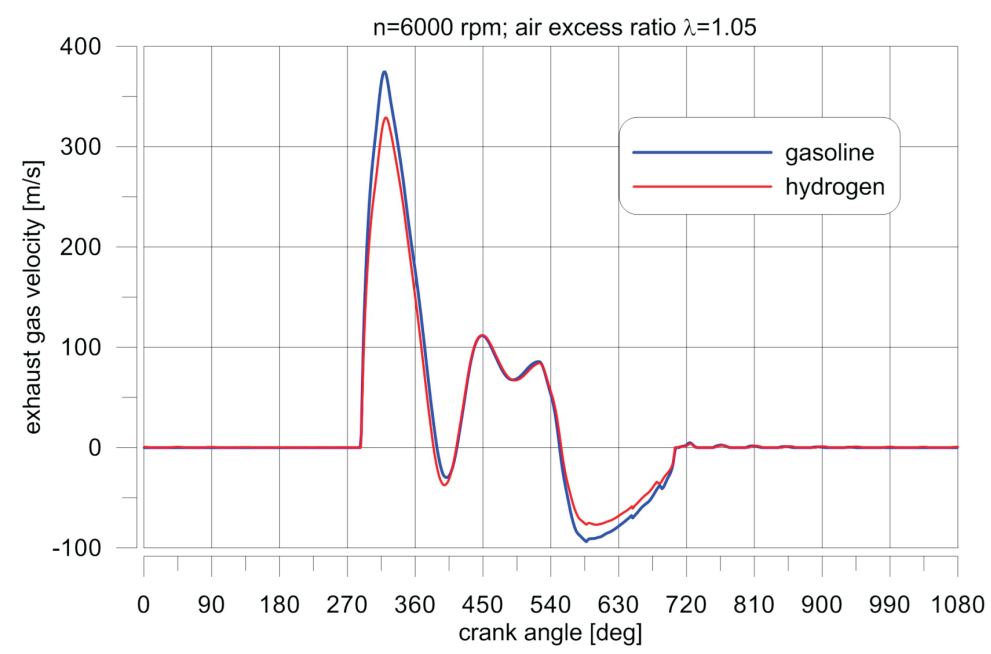

Fig. 7. Exhaust gas velocity behind the exhaust port for gasoline and hydrogen mixtures at $6000 \mathrm{rpm}$

Rys. 7. Prędkość gazów spalinowych za oknem wylotowym przy mieszance benzynowej $i$ wodorowej oraz przy prędkości obrotowej 6000 obr/min dzie dolotowym, które wywołuje również większe ciśnienie w oknie dolotowym. Najniższe ciśnienie wynosi 0,92 bar przy kącie obrotu wykorbienia $720^{\circ}$ i dla tego punktu pracy największa prędkość gazu w oknie wlotowym wynosi $60 \mathrm{~m} / \mathrm{s}$. W czasie przymykania okna dolotowego przez wirnik występuje silna oscylacja ciśnienia gazu.

Nieustalony przepływ gazu w oknie wylotowym powoduje także zmianę masy gazów opuszczających komorę spalania. Zmiana całkowitej masy gazów spalinowych jest przedstawiona na rys. 6 dla prędkości obrotowych 4000 i $8000 \mathrm{obr} / \mathrm{min}$. Powrotny przepływ gazów w przewodzie wylotowym wpływa na zmniejszenie ogólnej masy tych gazów, jako wynik odbicia fali ciśnienia. Otwarcie okna wylotowego trwa $400^{\circ}$ obrotu wykorbienia, a całkowita masa gazów opuszczających komorę roboczą wynosi 0,3 g i jest trochę mniejsza dla silnika pracującego przy większej prędkości obrotowej - 8000 obr/min. Przebieg zmiany całkowitej masy gazów spalinowych jest prawie taki sam dla różnych prędkości obrotowych przy pełnym otwarciu przepustnicy powietrza.

Fluktuacje ciśnienia w przewodzie wylotowym wpływają na zmianę prędkości gazów wylotowych, gdzie przewód ma małą długość $0,37 \mathrm{~m}$. Zmiana prędkości gazów wylotowych w silniku zasilanym benzyną i wodorem jest przedstawiona na rys. 7 dla prędkości obrotowej wykorbienia $6000 \mathrm{obr} / \mathrm{min}$ i współczynnika nadmiaru powietrza $\lambda=1,05$. Można zauważyć, że żaden rodzaj paliwa nie ma wpływu na przebieg prędkości gazów wylotowych. W pierwszym okresie otwarcia okna wylotowego jest duża wartość prędkości - około $360 \mathrm{~m} / \mathrm{s}$. Podczas przymykania okna wylotowego występuje wlot gazów do komory (porównaj z rys. 6).

Proces przepłukania decyduje o całkowitej masie ładunku w komorze. Ilość opuszczających komorę gazów spalinowych musi być taka sama jak ilość gazów wpływających do tej komory. Zmiana masy ładunku w komorze roboczej jest przedstawiona na rys. 8 dla dwóch prędkości obrotowych: 4000 i 6000 obr/min. Minimum masy występuje przy położeniu wykorbienia $630^{\circ} \mathrm{i}$ wynosi 0,019 g. Po zamknięciu okna dolotowego masa ładunku wynosi 0,458 g. Zmiana masy w komorze tylko nieznacznie się zmienia z prędkością wału korbowego

Podczas procesów przepłukania i spalania ilość gazów spalinowych i powietrza zmienia się. Przy współczynniku nadmiaru powietrza $\lambda>1$ gazy spalinowe zawierają trochę powietrza. Stosunek masowy powietrza i paliwa w ładunku zwiększa się podczas procesu zasysania, jednakże nigdy nie osiąga wartości równej 1,0. Zmiana stosunku masy gazów spalinowych i świeżego ładunku jest pokazana na rys. 9 dla prędkości obrotowej wykorbienia $8000 \mathrm{obr} / \mathrm{min}$.

Analiza rys. 9 wskazuje, że sprawność wolumetryczna wolnossącego silnika Wankla z obrotowym 


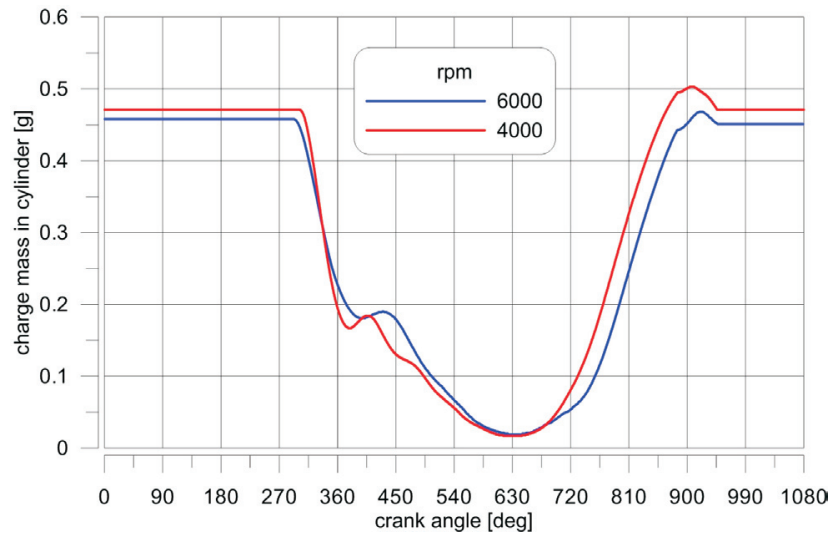

Fig. 8. Variation of total mass in the cylinder at 4000 and $6000 \mathrm{rpm}$ (engine fuelled with gasoline)

Rys. 8. Zmiana całkowitej masy ładunku w komorze przy prędkości obrotowej wykorbienia 4000 i 6000 obr/min (silnik zasilany benzyna)

however, never reaches value equal 1.0. Variation of mass ratio of exhaust gases and fresh charge is shown in Fig. 9 at rotational speed $8000 \mathrm{rpm}$.

The graph shows that volumetric efficiency for naturally aspirated rotary Wankel engine never exceeds value 1.0. During compression process the working chamber contains mixture with exhaust gases, air and injected fuel.

The rotary Wankel engine as a thermal machine executes an internal work. The current internal work changes during rotation of the crankshaft and piston. Figure 10 presents variation of the internal work in such engine during one piston rotation ( $1180 \mathrm{deg} \mathrm{CA})$ at $6000 \mathrm{rpm}$ and $\lambda=1.05$ for two cases: engine fuelled by gasoline and engine fuelled by hydrogen. Because of lower caloric value of hydrogen the engine fed by this fuel indicates lower internal work in comparison to the engine with gasoline system.

The maximum of internal work takes place at $360 \mathrm{deg}$ CA for both fuel. At the end of the working cycle the internal works amounts $500 \mathrm{~J}$ and $275 \mathrm{~J}$ for engine fuelled by gasoline and hydrogen, respectively. The engine executes

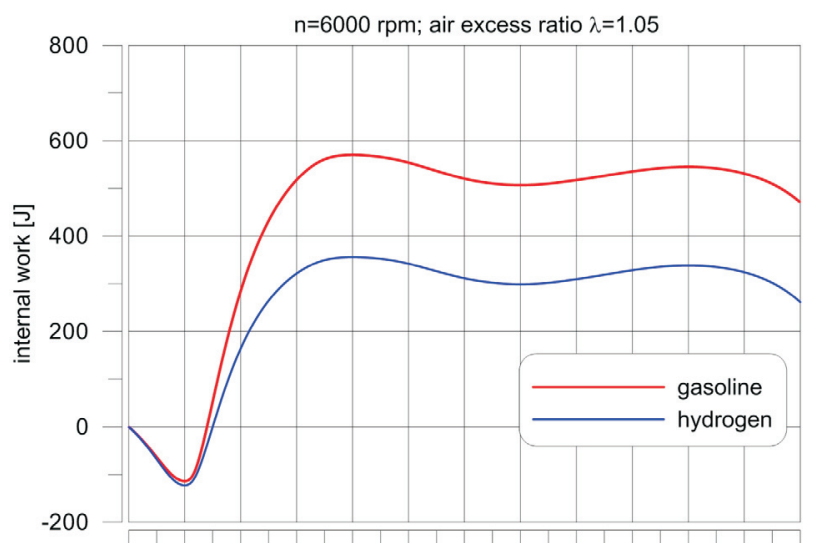

$\begin{array}{lllllllllllll}0 & 90 & 180 & 270 & 360 & 450 & 540 & 630 & 720 & 810 & 900 & 990 & 1080\end{array}$ crank angle [deg]

Fig. 10. Internal work of Wankel engine fuelled by gasoline and hydrogen

Rys. 10. Praca wewnętrzna silnika Wankla zasilanego benzyna $i$ wodorem

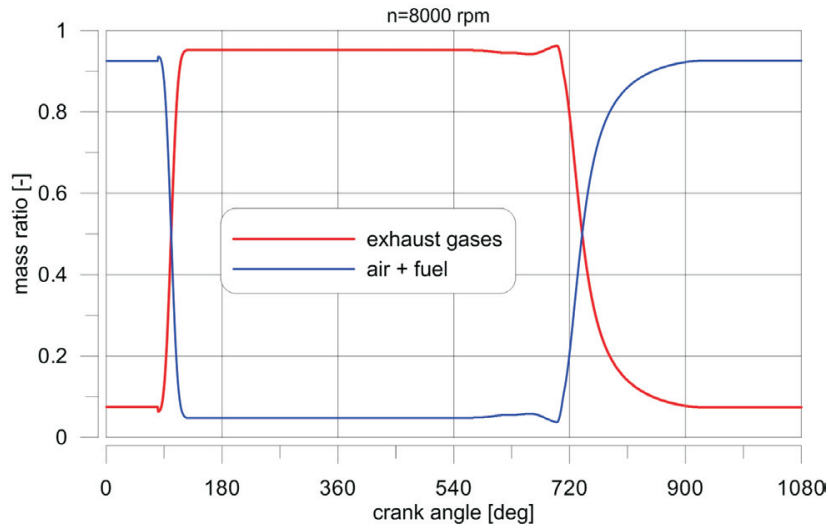

Fig. 9. Mass ratio of exhaust gases and air-fuel mixture of the charge in the cylinder at $8000 \mathrm{rpm}$

Rys. 9. Stosunek masy gazów spalinowych i mieszanki powietrzno-paliwowej ładunku w komorze przy 8000 obr/min

tłokiem nigdy nie przekracza wartości 1,0. Podczas procesu sprężania komora robocza zawiera mieszaninę gazów spalinowych, powietrze i wtryśnięte paliwo. Rotacyjny silnik Wankla jako maszyna cieplna wykonuje pracę wewnętrzną, która zmienia się na bieżąco w czasie obrotu wału korbowego i tłoka. Na rysunku 10 przedstawiono zmienność pracy wewnętrznej w tym silniku dla jednego obrotu tłoka $\left(1180^{\circ}\right.$ OWK) przy prędkości obrotowej $6000 \mathrm{obr} / \mathrm{min}$ i $\lambda=1,05$ dla dwóch przypadków: silnik zasilany benzyną i zasilany wodorem. Z powodu małej wartości opałowej wodoru silnik zasilany tym paliwem wykazuje mniejszą pracę wewnętrzną w porównaniu do silnika zasilanego benzyną.

Maksimum pracy wewnętrznej dla jednego cyklu roboczego występuje przy kącie obrotu wykorbienia $360^{\circ}$ dla obydwu paliw. Przy końcu cyklu roboczego prace wewnętrzne wynoszą odpowiednio $500 \mathrm{~J}$ i $275 \mathrm{~J}$ dla silnika zasilanego benzyną i wodorem. Silnik wykonuje ujemną pracę w procesie sprężania, która wynosi około $100 \mathrm{~J}$ przy zasilaniu obydwoma paliwami. Praca wykonana przez silnik była wyznaczona dzięki zastosowaniu generalnej formuły stosowanej w termodynamice (18),

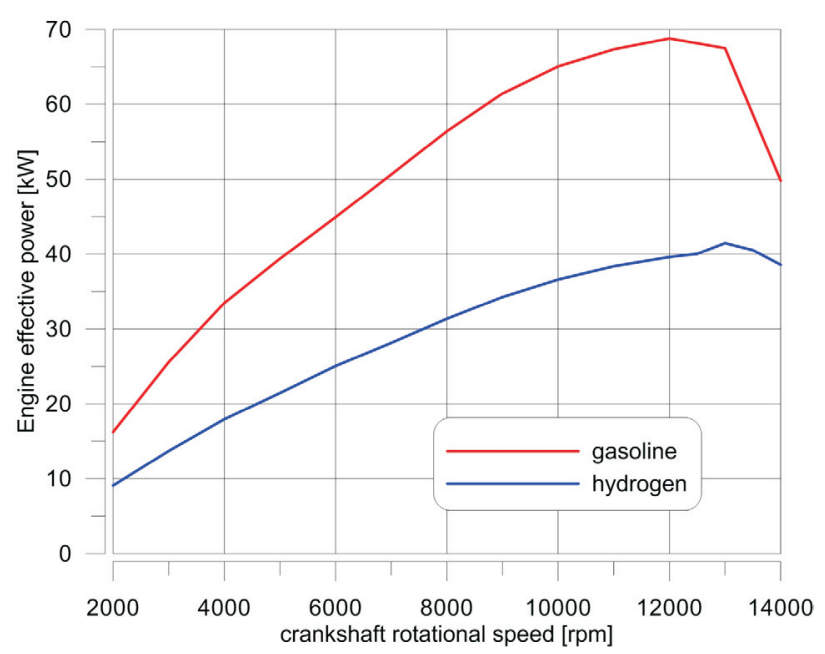

Fig. 11. Power performance of engine fuelled with gasoline and hydrogen

Rys. 11. Charakterystyka mocy silnika zasilanego benzyna i wodorem 
a negative internal work during compression process, which amounts $100 \mathrm{~J}$ equal for both fuels. The work done by engine was determined by using the general form used in thermodynamics:

$$
\mathrm{L}=\int_{0}^{\alpha=1} \mathrm{pdV}
$$

where $\mathrm{dV}$ is an increment of volume at crankshaft position $\alpha$.

The computer program enables calculation of rotary Wankel engine working parameters. The engine power is a sum of power of three working chambers and this machine works as two-stroke engine. Knowing an internal work and assuming a certain value of mechanical losses, the power of the engine can be determined for every rotational speed (time is known). Figure 11 presents foreseen engine performance of power in the range 2000 and $15000 \mathrm{rpm}$ for engine fuelled by gasoline and hydrogen. The picture shows the engine power for three working chambers.

The engine with hydrogen fuelling system has almost twice lower power than engine with gasoline system. For both engines maximum of power occurs at rotational speed $12000 \mathrm{rpm}$ and amounts $70 \mathrm{~kW}$ for gasoline engine and $40 \mathrm{~kW}$ for hydrogen engine. The air excess ratio for both engines amounted 1.05, while the engine operated at full throttle opening.

\section{Conclusions}

The work contains the information concerning the main thermodynamic processes in the rotary Wankel engine. This engine is still attractive for transportation particularly for aviation, where smoothness of the work, high power density, lack of vibration and small dimensions are more taken into account than other working parameters. The work was connected with elaboration of computer program supported on physical phenomena with given 0-D and 1-D mathematical models.

The simulation process enabled to determine thermodynamic parameters of the processes. One of the important factors was a determination of changeable engine geometry in a function of crankshaft rotation angle. At assumed engine geometry the work presents results of scavenge process and final working parameters such as power and internal work.

On the basis of presented mathematical model and results received from simulation of scavenge process and combustion process the following remarks can be drawn:

1. During opening the inlet port only small time period is used for filling the working chamber by fresh air. Outflow of exhaust gases lasts a long time due to high pressure. It depends obviously on the exhaust port area, but for well sealing the contact apexes of rotor should be short as possible.

2. For natural aspirated rotary Wankel engine volumetric efficiency is still below 1.0, because the exhaust gases restrain the flow of air into the working chamber.

3. Fuel injection should take place during compression process in order to decrease the fuel losses. gdzie dV jest przyrostem objętości przy położeniu wykorbienia $\alpha$.

Program komputerowy umożliwia obliczenie parametrów roboczych silnika Wankla. Moc silnika jest sumą mocy trzech komór roboczych, przy czym silnik pracuje w trybie dwusuwowym. Znając pracę wewnętrzną i zakładając pewne wartości strat mechanicznych, moc silnika może być określona dla każdej prędkości obrotowej (znany jest czas). $\mathrm{Na}$ rysunku 11 przedstawiono przewidywaną charakterystykę mocy silnika w zakresie prędkości obrotowych wału korbowego od 2000 do $15000 \mathrm{obr} / \mathrm{min}$ dla silnika zasilanego benzyną i wodorem - przedstawiono moc silnika dla trzech komór roboczych.

Silnik z systemem zasilania wodorem wykazuje prawie dwukrotnie mniejszą moc niż silnik z systemem zasilania benzyną. Dla obydwu silników maksimum mocy występuje przy prędkości obrotowej $12000 \mathrm{obr} / \mathrm{min}$ i wynosi $70 \mathrm{~kW}$ dla silnika benzynowego, a $40 \mathrm{~kW}$ dla silnika wodorowego. Współczynnik nadmiaru powietrza dla obydwu silników wynosił 1,05 , przy czym silnik pracował przy pełnym otwarciu przepustnicy powietrza.

\section{Wnioski}

Niniejsza praca zawiera informacje dotyczące głównych procesów termodynamicznych w silniku Wankla z łłokiem obrotowym. Ten silnik jest ciągle atrakcyjny dla transportu, szczególnie dla lotnictwa, gdzie równomierność pracy, duża jednostkowa moc, brak drgań oraz małe wymiary są brane bardziej pod uwagę niż inne parametry robocze. Praca była połączona $\mathrm{z}$ opracowaniem programu komputerowego opartego na zjawiskach fizycznych opisanych modelami matematycznymi 0-D i 1-D.

Proces symulacyjny umożliwił określenie parametrów termodynamicznych procesów silnikowych. Jednym z ważniejszych aspektów było określenie zmienności geometrii silnika w funkcji kąta obrotu wykorbienia. Przy założonych głównych wymiarach silnika praca przedstawia wyniki procesu przepłukania oraz parametry finalne, takie jak moc oraz praca wewnętrzna. Na podstawie podanego modelu matematycznego oraz wyników otrzymanych z symulacji procesu przepłukania i spalania podano następujące spostrzeżenia:

1. Podczas otwarcia okna dolotowego tylko mała część tego okresu jest wykorzystana do napełnienia komory świeżym powietrzem. Wypływ gazów spalinowych trwa przez długi okres z powodu dużego ciśnienia w komorze. Zależy to oczywiście od pola powierzchni okna wylotowego, lecz dla dobrego uszczelnienia kontakt wierzchołków rotora z oknem powinien być jak najkrótszy.

2. Dla wolnossącego silnika Wankla stopień napełnienia jest w dalszym ciągu poniżej wartości 1,0, ponieważ gazy spalinowe powstrzymują napływ świeżego powietrza do komory.

3. Wtrysk paliwa powinien występować podczas procesu sprężania, aby nie dopuścić do strat paliwa.

4. Silnik zasilany jednorodną mieszanką benzynowo-powietrzną wykazuje większą pracę wewnętrzną (także moc) niż silnik z mieszanką wodorowo-powietrzną z powodu 
4. Engine working with gasoline homogenous mixture indicates higher internal work (also power) than the engine with hydrogen mixture due to higher caloric value of gasoline at the same regulation parameters.

5. Mass of charge in the naturally aspirated Wankel engine changes slightly for different rotational speeds.

6. Exhaust pressure in the port is almost independent from the fuel at the same rotational speed.

7. Rotary engine indicates maximum of power at high rotational speed, in the considered case at $12000 \mathrm{rpm}$.

8. For higher total efficiency engine should be equipped with direct fuel injection system in order to obtain a stratified charge.

The work presents only some specific parameters for such engine in regards to scavenge process, which is very important for ported engine. The literature has not contained such information obtained from simulation and experimental works. większej wartości opałowej benzyny przy tych samych parametrach regulacyjnych.

5. Masa ładunku w wolnossącym silniku Wankla zmienia się nieznacznie z prędkością obrotową wykorbienia.

6. Ciśnienie gazu w oknie wylotowym jest prawie niezależne od rodzaju paliwa przy tej samej prędkości obrotowej wykorbienia.

7. Silnik z tłokiem obrotowym wykazuje maksimum mocy przy dużych prędkościach obrotowych, w rozważanym przypadku przy $12000 \mathrm{obr} / \mathrm{min}$.

8. Do uzyskania dużej sprawności ogólnej silnik powinien być wyposażony w system bezpośredniego wtrysku paliwa w celu otrzymania uwarstwionego ładunku.

Artykuł przedstawia tylko niektóre wybrane parametry dla tego silnika w odniesieniu do procesu przepłukania, który jest bardzo ważny dla silników z rozrządem szczelinowym. Literatura nie zawiera takich informacji otrzymanych na drodze symulacji oraz badań eksperymentalnych.

\section{Nomenclature/Skróty i oznaczenia}

DISC Direct Injection Stratified Charge/wtrysk bezpośredni tworzacy uwarstwiony tadunek

CA Crank Angle/kąt obrotu watu korbowego crevice/szczelina

$\lambda \quad$ Air Excess Ratio/wspótczynnik nadmiaru powietrza

\section{Bibliography/Literatura}

[1] Ramos J.I. Internal combustion engine modelling, Hemisphere Publishing Corporation, New York.

[2] Wankel F. Rotary piston machines, classification of design principles for engine, pumps and compressors, London Life Books, London 1963.

[3] Okhubo M., Tashima S., Shimizu R., Fuse S., Ebino H. Developed technology of the new rotary engine, SAE Paper 2004-01-1790, Warrendale, 2004.

[4] Keck J.C., Heywood J.B. Experimental and theoretical analysis of Wankel engine performance, SAE Paper 780416, Warrendale, 1978.

[5] Bartrand T., Willis E. Performance of a supercharged direct injection stratified charge rotary combustion engine, NASA Technical Memorandum 103105, Ocean City, NJ 1990.

[6] Szlachetka M., Wendeker M., Czarnigowski J., Jaklinski P., Grabowski Ł. A simulation research of a hydrogen injection system for a Wankel engine, Combustion Engines, PTNSS2010-SS2-214, No. 2/2010 (141) pp. 114-122, Bielsko-Biala 2010.

Mitianiec Władysław, DSc., DEng. - Professor of Cracow University of Technology in the Faculty of Mechanical Engineering at CUT.

Dr hab. inż. Wladystaw Mitianiec - Profesor nadzwyczajny na Wydziale Mechanicznym Politechniki Krakowskiej.

e-mail:wmitanie@usk.pk.edu.pl
[7] Rannacher R., Heuveline V. A numerical tool for flow simulation in a Wankel motor, Institut für Angewandte Mathematik, Universität Heidelberg, 2000.

[8] Yamamoto K., Rotary engine, Toyo Kogyo Co, Ltd, Tokyo 1981.

[9] Drogosz P. Trajectory of the apex seals ot the Wankel rotary engine, Journal of KONES Powertrain and Transport, Vol. 18, No 2, Warszawa 2011.

[10] Izweik H.T. Mixture formation, flow and combustion for multi-fuel rotary engine, Doctor Thesis, Brandenburgischen Technischen Universität Cottbus 2009.

[11] Warren S.E. New rotary engine designs by deviation function method, Doctor Dissertation, University of California, Los Angeles 2012.

[12] Ma H., Kuo C., Chen C. Chamber contour design and compression flow calculations of rotary engine, Journal of C.C.I.T., Vol.39, No.1, May, 2010.

[13] Votaw Z.S. Computational Study on micropilot flame ignition strategy for a direct injection stratified charge rotary engine, MSc Thesis, Wright State University, 2012.

[14] Mitianiec W. Wtrysk paliwa w silnikach dwusuwowych małej mocy. Polska Akademia Nauk, ISDN-83-87854-31-X, Kraków 1999.

[15] Zhao Y. et al. CFD simulation of a pump with Wankel engine geometry, The 11th Asian International Conference on Fluid Machinery and the 3rd Fluid Power Technology Exhibition, Madras, Chennai, India, 2011. 